\title{
Effect of continuous infusion of thyrotrophin-releasing hormone on plasma prolactin and on ovarian activity in melatonin-treated ewes
}

\author{
J. J. Robinson ${ }^{1 *}$, R. P. Aitken ${ }^{1}$, T. Atkinson ${ }^{1}$, J. M. Wallace ${ }^{1}$ and \\ A. S. McNeilly ${ }^{2}$ \\ ${ }^{\mathrm{I}}$ Rowett Research Institute, Bucksburn, Aberdeen, AB2 9SB, UK; and ${ }^{2} M R C$ Reproductive Biology Unit, \\ Centre for Reproductive Biology, 37 Chalmers Street, Edinburgh, EH3 9EW, UK
}

\begin{abstract}
Twelve anoestrous ewes maintained under natural photoperiod at $57^{\circ} \mathrm{N}$ received an oral dose of $3 \mathrm{mg}$ melatonin daily at 15:00 h from I May. Starting 41 days later and extending from 11 June until 5 September, six of the ewes were also infused continuously with $0.8 \mathrm{mg}$ thyrotrophin-releasing hormone (TRH) day ${ }^{-1}$ via subcutaneous osmotic minipumps. The remaining six ewes acted as controls. Behavioural oestrus, ovulation rate and luteal function were determined by exposure to a vasectomized ram, laparoscopy and the measurement of progesterone in peripheral plasma, respectively. TRH infusion stimulated a sustained increase $(P<0.001)$ in plasma concentrations of thyroxine, tri-iodothyronine and prolactin (thyroxine: $158 \pm 9.3$ and $65 \pm 7.7 \mathrm{nmol} \mathrm{l}^{-1}$ for TRH-infused and control ewes, respectively; tri-iodothyronine, $2.6 \pm 0.12$ and $1.1 \pm 0.19 \mathrm{nmol} \mathrm{l}^{-1}$ and prolactin, $57 \pm 12$ and $\left.11 \pm 2 \mu \mathrm{g} \mathrm{l}^{-1}\right)$. No ewes were in oestrus before the TRH infusion and the mean number of behavioural oestrous cycles per ewe during the infusion period was $1.3 \pm 0.33$ and $2.5 \pm 0.34$ for TRH-infused and control ewes, respectively $(P<0.05)$. Corresponding mean intervals from 1 May to the onset of the first luteal phase (progesterone $>1 \mathrm{ng} \mathrm{ml}^{-1}$ ) were $88 \pm 8.9$ and $79 \pm 3.5$ days (not significant). TRH infusion had no effect on the mean numbers of corpora lutea ( $1.7 \pm 0.14$ and $1.6 \pm 0.20$ for TRH-infused and control ewes, respectively), but was associated with a lower mean incidence of normal luteal phases ( $1.5 \pm 0.43$ versus $2.7 \pm 0.21, P=0.052$ ). Abnormalities in luteal function included delayed initial expression, extended ovarian cycles, suprabasal periovulatory progesterone concentrations and protracted periods of low progesterone secretion between successive ovarian cycles. Thus continuous TRH infusion suppressed plasma prolactin, doubled the circulating concentrations of thyroxine and tri-iodothyronine, and was associated with a wide range of abnormalities in ovarian function and endocrine status, the nature of which varied between ewes.
\end{abstract}

\section{Introduction}

The thyroid gland plays an essential role in mediating the transition to the non-breeding season in species such as sheep (Nicholls et al., 1988) and deer (Shi and Barrell, 1992), whose seasonal pattern of reproduction is linked to photoperiodic signals involving the pineal hormone melatonin (Karsch et al., 1984). More specifically, after the initiation of oestrous cyclicity, thyroxine is required to programme the change in oestradiol negative feedback that leads to the inactivation of the GnRH pulse generator (Webster et al., 1991) and the termination of the breeding season. Although the initial demonstration of the role of the thyroid was based on the observation that thyroidectomy prevented the transition to

*Present address: Animal and Feed Technology Department, SAC, Ferguson Building, Craibstone Estate, Bucksburn, Aberdeen, AB2 9YA, UK.

Revised manuscript received 10 January 1996. anoestrus (Nicholls et al., 1988), whereas thyroidectomy in combination with thyroxine replacement therapy did not (Webster et al., 1991), there is evidence that the relationship between thyroxine concentrations and the timing of the transition to anoestrus is quantitative. For example, oral administration of methylthiouracil to create a moderate degree of hypothyroidism in ewes causes a significant delay in their transition to anoestrus (Follett and Potts, 1990). In contrast, daily injections of thyroxine cause premature anoestrus (O'Callaghan et al., 1993).

Whether alterations in thyroid function perturb the programming of photoperiodic information and the melatonin signal in a manner that influences the onset, as opposed to the termination, of the natural breeding season is unknown. Daily oral administration of melatonin, at 15:00 $\mathrm{h}$ from the beginning of May, to ewes maintained under a highly seasonal natural photoperiod $\left(57^{\circ} \mathrm{N}\right)$ advanced the onset of frequent LH pulses and first ovulation by 47 days, 25 July versus 10 September 
(Robinson et al., 1992). The same treatment also reduced plasma prolactin secretion within 10 days to concentrations normally observed in the breeding season. The effect of altered thyroid function in this situation has not been tested. A direct inhibitory effect of increased prolactin on ovarian function was observed during intravenous injections of thyrotrophinreleasing hormone (TRH) given every $2 \mathrm{~h}$ for $60 \mathrm{~h}$ after prostaglandin-induced luteolysis (McNeilly and Baird, 1983). The objective of the present experiment was to test the effects of increased prolactin concentrations, induced by long-term continuous TRH infusion, on reproductive function in melatonin-treated ewes.

\section{Materials and Methods}

\section{Animals and treatments}

Twelve anoestrous ewes were used in the study. Ten were 4- to 5 -year-old Border Leicester $\times$ Scottish Blackfaces and two were 6-year-old identical twin Suffolk $\times$ Finn Dorsets. The natural breeding season of both breeds extends from September-October to February-March. They were housed in individual pens under natural daylength conditions at the Rowett Research Institute $\left(57^{\circ} \mathrm{N}\right)$ and each was given $1.4 \mathrm{~kg}$ of a complete diet containing milled hay, barley, fish meal and molasses daily. The diet was supplemented with minerals and vitamins and supplied 12.6 MJ of metabolizable energy and $175 \mathrm{~g}$ crude protein daily. The feed was offered in two equal portions at $08: 00$ and $16: 00 \mathrm{~h}$ each day. From the beginning of May each ewe received an oral dose of $3 \mathrm{mg}$ melatonin (Sigma Chemical Co., Poole, Dorset) in a $4: 1$ (v:v) mixture of water and alcohol daily at 15:00 h. Forty-one days later, on 11 June, five of the Border Leicester $\times$ Scottish Blackfaces and one of the identical twins were implanted with an osmotic minipump (Alzet osmotic pumps model 2ML4; Alza Corp., Palo Alto, CA) containing $2 \mathrm{ml}$ TRH (Peninsula Laboratories Europe, St Helens, Lancs; infusion rate $0.8 \mathrm{mg}^{\text {day }}{ }^{-1}$ ). Before insertion, the minipumps were incubated for $20 \mathrm{~h}$ in physiological saline at $37^{\circ} \mathrm{C}$. Insertion below the skin overlying the ribs was carried out under local anaesthesia induced by a s.c. injection of $10 \mathrm{ml}$ Lignovet-plus (C-Vet Ltd, Bury St Edmunds). Second and third minipumps containing the same amount of TRH were inserted on 8 July (day 68) and 4 August (day 95), respectively, to ensure a continued infusion of TRH until anticipated exhaustion of the third minipump in early September. All minipumps were removed on 23 October (day 175) when melatonin treatment stopped and the experiment was terminated. Ewes were weighed at the beginning and end of the TRH infusion period.

\section{Reproductive actioity and endocrine status}

From 11 June, ewes were exposed, on an individual basis once a day, to a vasectomized ram for the detection of behavioural oestrus. Ovarian function was also assessed by laparoscopy on 19 June (that is, 8 days after minipump insertion), 6 July, 23 July, 14 August and 11 September. Blood samples were taken three times a week (Monday, Wednesday and Friday) until the day before insertion of the minipump and thereafter once a day. All samples were analysed for prolactin and, those obtained from 3 days before minipump insertion until the end of the experiment were analysed for thyroxine, tri-iodothyronine and progesterone. Blood samples for the determination of $\mathrm{LH}$ secretion were taken more frequently from all ewes via a jugular cannula, at intervals of $15 \mathrm{~min}$ from 07:00 to 19:00 h on the day before the first minipump was inserted and again 7 days later.

\section{Hormone assays}

Concentrations of thyroxine and tri-iodothyronine were measured in duplicate by radioimmunoassay using sheep antisera (Scottish Antibody Production Unit, Carluke, Lanarkshire). The sensitivities of the assays were 12.5 and $0.2 \mathrm{pmol} \mathrm{ml}^{-1}$ for thyroxine and tri-iodothyronine, respectively. Intra- and interassay coefficients of variation were 7.4 and $13.5 \%$, respectively for thyroxine and 4.9 and $9.6 \%$ for tri-iodothyronine. Concentrations of prolactin and $\mathrm{LH}$ were measured in duplicate by specific double-antibody radioimmunoassays (McNeilly and Andrews, 1974; McNeilly et al., 1986). The sensitivities of the assays were $0.08 \mu \mathrm{g}$ prolactin $1^{-1}$ (NIADDK-oPrl-17) and $0.5 \mu \mathrm{g} \mathrm{LH} \mathrm{I}^{-1}$ (NIADDK-oLH-25). The intra- and interassay coefficients of variation were $3.9 \%$ and $5.9 \%$ for prolactin, and $4.5 \%$ and $8.6 \%$ for $\mathrm{LH}$, respectively. Progesterone concentrations were measured in $100 \mu \mathrm{l}$ aliquots of plasma by radioimmunoassay (Djahanbakhch et al., 1981). Intra- and interassay coefficients of variation were $10.1 \%$ and $11.5 \%$, respectively. The detection limit was $0.3 \mathrm{ng} \mathrm{ml}^{-1}$ and the recovery of progesterone from plasma was $64 \pm 1.6 \%$ (SEM; $n=1700$ ).

\section{Definitions and data analysis}

Ewes were recorded as exhibiting behavioural oestrus when they stood to be mounted and mated by a vasectomized ram. The onset of ovarian activity was defined as the first of a series of three or more daily progesterone concentrations in plasma to exceed $1.0 \mathrm{ng} \mathrm{ml}^{-1}$ and the validity of this threshold value was confirmed by the presence of a macroscopically normal corpus luteum at laparoscopy. During the period of frequent blood sampling (intervals of $15 \mathrm{~min}$ ) an increase in $\mathrm{LH}$ was considered to be a pulse if the value of two consecutive samples was greater than the mean of the two previous samples (basal value) and the value of at least one of the peak samples exceeded the mean basal value by more than four times the intra-assay coefficient of variation (Backstrom et al., 1982).

\section{Statistical analyses}

Data for thyroxine, tri-iodothyronine and prolactin were summarized by linear contrasts defined within each animal and these were analysed by analysis of variance for the effect of TRH infusion. The discrete LH pulse data were analysed by a generalized linear model using GENSTAT (GENSTAT 5 Committee, 1990). Student's $t$ test was used to determine the effects of TRH infusion on the timing of first ovulation and first behavioural oestrus, and the Mann-Whitney $U$ test for effects 

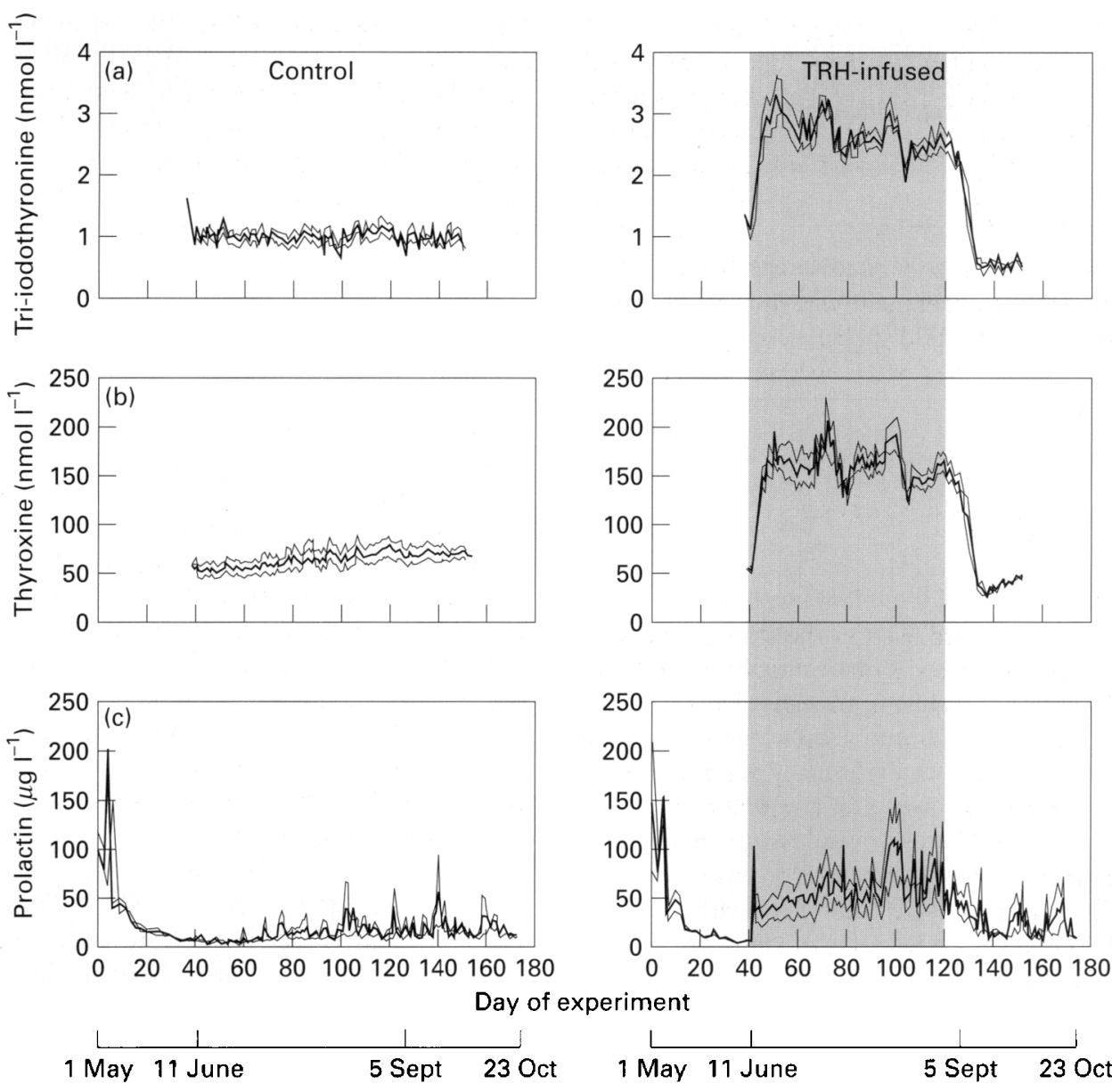

Fig. 1. Daily concentrations of (a) tri-iodothyronine, (b) thyroxine and (c) prolactin in control and thyrotrophin-releasing hormone (TRH)-infused ewes maintained under natural photoperiod at $57^{\circ} \mathrm{N}$ and receiving an oral dose of $3 \mathrm{mg}$ melatonin at 15:00 h each day from 1 May. The upper and lower boundaries for each profile are + and - , respectively, I SE from the daily means. The shaded region indicates the period of TRH infusion.

on the incidence of behavioural oestrus and the number of corpora lutea at laparoscopy.

\section{Results}

Plasma concentrations of prolactin decreased from $>100 \mu \mathrm{g} \mathrm{I}^{-1}$ to $\sim 10 \mu \mathrm{g} \mathrm{I}^{-1}$ within 3 weeks of starting the melatonin treatment, and then immediately increased $(P<0.001)$ with TRH infusion and remained raised until 5 September, that is, 86 days from the start of infusion (Fig. 1). The mean ( \pm SEM) concentration of prolactin during the infusion was $57 \pm 12 \mu \mathrm{g} \mathrm{l}^{-1}$ compared with $11 \pm 2 \mu \mathrm{g} \mathrm{l}^{-1}$ for control ewes. TRH infusion also stimulated a sustained increase $(P<0.001)$ in plasma concentrations of tri-iodothyronine and thyroxine (triiodothyronine: $2.6 \pm 0.12$ and $1.1 \pm 0.19 \mathrm{nmol}^{-1}$ for TRHtreated and control ewes, respectively; corresponding values for thyroxine: $158 \pm 9.3$ and $65 \pm 7.7 \mathrm{nmol} \mathrm{l}^{-1}$ ). During the infusion period the mean change in body mass of treated ewes was $-3.5 \mathrm{~kg}$ compared with $+0.9 \mathrm{~kg}$ for controls $(P=0.027)$.

No ewes exhibited oestrus before the TRH infusion. On the day before insertion of the minipump mean basal $\mathrm{LH}$ concentrations $\left(0.53 \pm 0.02 \mu \mathrm{g} \mathrm{^{-1 }}\right)$ were similar to those observed 8 days later $\left(0.50 \pm 0.04 \mu \mathrm{g} \mathrm{l}^{-1}\right)$ by which time concentrations of prolactin, thyroxine and tri-iodothyronine had increased in response to TRH infusion. The corresponding frequency of LH pulses $\left(1.2 \pm 0.31\right.$ versus $\left.1.5 \pm 0.22(12 \mathrm{~h})^{-1}\right)$ and the mean pulse amplitudes $(3.6 \pm 0.83$ versus $3.0 \pm$ $1.14 \mu \mathrm{g} \mathrm{l}^{-1}$ ) were also not significantly affected by the rapid increases in plasma prolactin, thyroxine and tri-iodothyronine concentrations. Thus all measures of $\mathrm{LH}$ in TRH-infused ewes were not significantly different from those observed in control ewes.

Apart from a single ovulation leading to a non-functional corpus luteum (no increase in progesterone concentrations) in one ewe (No. 755), continuous infusion with TRH did not significantly affect either the timing of the first increase in plasma progesterone or ovulation rate. It did, however, reduce the incidence of behavioural oestrus and the number of normal ovarian cycles (Table 1).

The nature of the abnormalities in ovarian function expressed by four of the six ewes treated with TRH compared with none of the six control ewes are illustrated (Fig. 2). The 
Table 1. Mean intervals ( $\pm \operatorname{SEM}, n=6$ ) from the start of melatonin treatment to first increase in progesterone concentrations for ewes receiving either melatonin alone (control) or in combination with infusion of thyrotrophin-releasing hormone (TRH-infused), together with measures of oestrous cyclicity, luteal function and ovulation rate during the period of TRH infusion

\begin{tabular}{lccc}
\hline Parameter & Control & TRH-infused & Significance \\
\hline Interval to first increase in progesterone (days) & $79 \pm 3.5$ & $88 \pm 8.9$ & NS \\
Incidence of behavioural oestrus during TRH infusion & $2.5 \pm 0.34$ & $1.3 \pm 0.33$ & $P<0.05$ \\
Number of normal luteal phases & $2.7 \pm 0.21$ & $1.5 \pm 0.43$ & $P=0.052$ \\
Ovulation rate* & $1.7 \pm 0.14^{\dagger}$ & $1.6 \pm 0.20$ & NS \\
\hline
\end{tabular}

NS: not significant.

*Excludes anovulatory observations

$+n=5$.

abnormalities included a delay in the initial increase in progesterone concentrations (Ewe No. 755), extended periods of progesterone secretion following normal initiation (752 and $829)$, protracted intervals of low progesterone secretion between successive cycles (752 and 760) and suprabasal periovulatory progesterone concentrations (760). The individual progesterone profiles for ewes 828 and 829 (Fig. 2) are of interest as these two animals are identical twins. A comparison of their progesterone profiles therefore provides a direct measure of the disruptive influence of continuous TRH infusion on luteal function in the absence of genetic variation. In this specific comparison, the most notable disruption was a very extended luteal phase.

The end of TRH infusion was marked by a consistent and rapid fall in plasma thyroxine and tri-iodothyronine to concentrations below those of controls. Although thyroxine concentrations subsequently increased, they were still below $(P<0.001)$ those of controls 2 weeks later when assaying for the hormone ceased. During this period prolactin concentrations returned to values that were not significantly different from controls and when the experiment terminated on 23 October ( 7 weeks after TRH infusion ceased) normal oestrous cyclicity and luteal function had returned to all but one of the TRH-infused ewes (ewe 760, Fig. 2).

\section{Discussion}

Continuous infusion of TRH stimulated a twofold increase in plasma concentrations of thyroxine and tri-iodothyronine and this increase was sustained for the entire period of infusion. At the same time, TRH increased plasma prolactin to concentrations observed previously in control ewes that were not treated with melatonin and were kept under the natural long-day photoperiod that prevails at $57^{\circ} \mathrm{N}$ (Robinson et al., 1993). Despite these increases in the circulating concentrations of the thyroid hormones and the associated increase in prolactin to 'long-day' values, a statistically significant alteration in the time of onset of ovarian activity was not observed. However, one of the six TRH-treated ewes (ewe 755) remained anoestrous during the period of TRH infusion and did not ovulate until 39 days after the last control (melatonin alone) ewe. Since an absence of ewes that fail to respond and small between-ewe variation in the onset of ovarian activity are characteristic features of daily oral dosing with melatonin during seasonal anoestrus (Robinson et al., 1993; control ewes in the present study), the delay in the onset of ovarian activity until after the TRH infusion had stopped, albeit in only one ewe, may be important and merits further study. Perhaps in some instances TRH disrupts the programming of the melatonin signal or interferes with its transmission to the $\mathrm{GnRH}$ pulse generator. It seems unlikely that TRH directly inhibits gonadotrophin release (McNeilly and Baird, 1983); this view is supported by the failure of TRH to have any immediate effect on LH secretion in the present study.

Unlike the uniform fore-shortening of the breeding season observed in ewes receiving injections of thyroxine (O'Callaghan et al., 1993) and the equally uniform delay in the attainment of puberty when ram lambs were similarly treated (Chandrasekhar et al., 1985), the increase in thyroxine resulting from TRH infusion in the present study caused a range of disruptions to reproductive function. As well as the extended duration of anoestrus observed in one ewe, these disruptions included a reduction in the incidence of behavioural oestrus, abnormally high peri-ovulatory/basal progesterone concentrations, extended luteal phases and a delay in the increase in progesterone concentrations following regression of the corpus luteum. This variable nature of the effect of TRH infusion is intriguing. It may indicate that the TRH-induced increase in the concentrations of the thyroid hormones brought them into a range where their effects on reproduction were chronic rather than acute. Certainly the increase in thyroxine in the present experiment was lower ( 2.4 times control values) than that $(4.5$ times control values) which caused delayed puberty in 100 per cent of treated ram lambs (Chandrasekhar et al., 1985). Indirect observations suggest that it was also lower than that induced by O'Callaghan et al. (1993) using injected thyroxine in that the average loss of mass of their ewes was $8.2 \mathrm{~kg}$ compared with $3.5 \mathrm{~kg}$ for those in the present experiment. Strong arguments are advanced by O'Callaghan et al. (1993) that the $8.2 \mathrm{~kg}$ weight loss is unlikely to account mechanistically for the fore-shortening of the breeding season induced by thyroxine, and based on observations for undernourished ewes receiving melatonin (Robinson et al., 1991) the loss of mass of $3.5 \mathrm{~kg}$ observed in the TRH-infused ewes in the present study would 

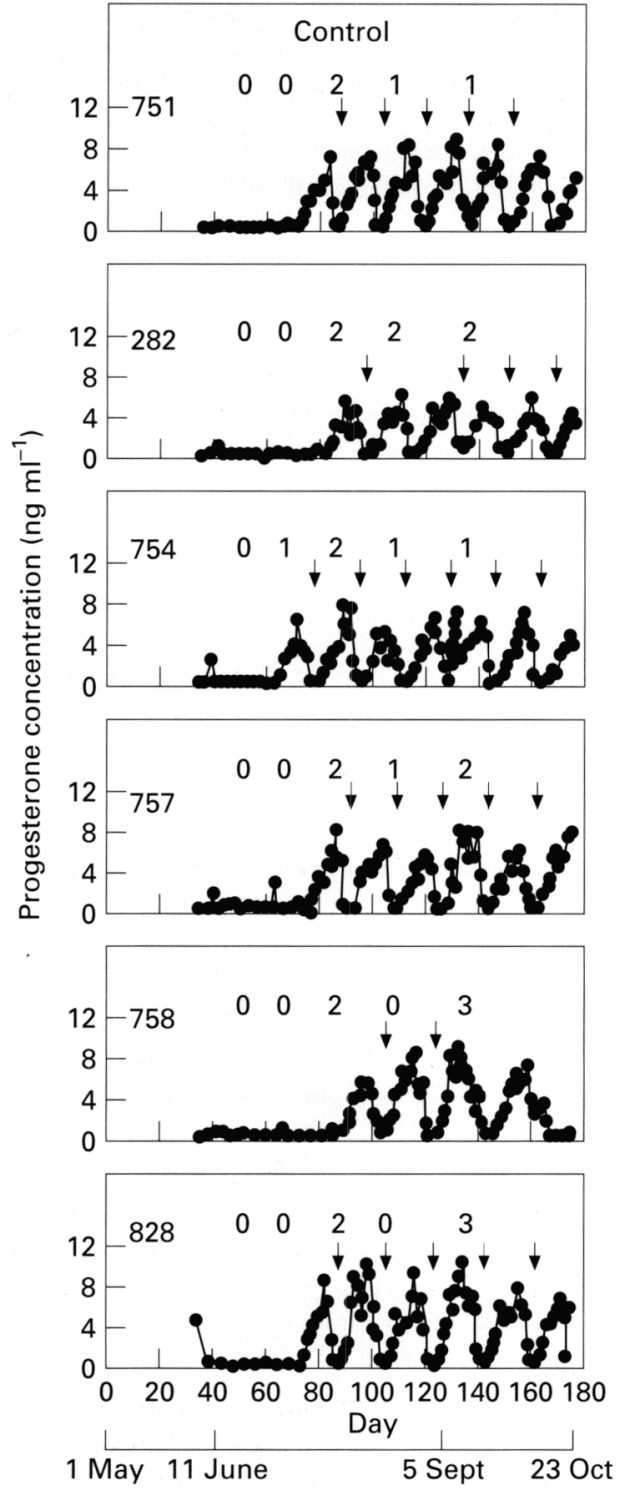
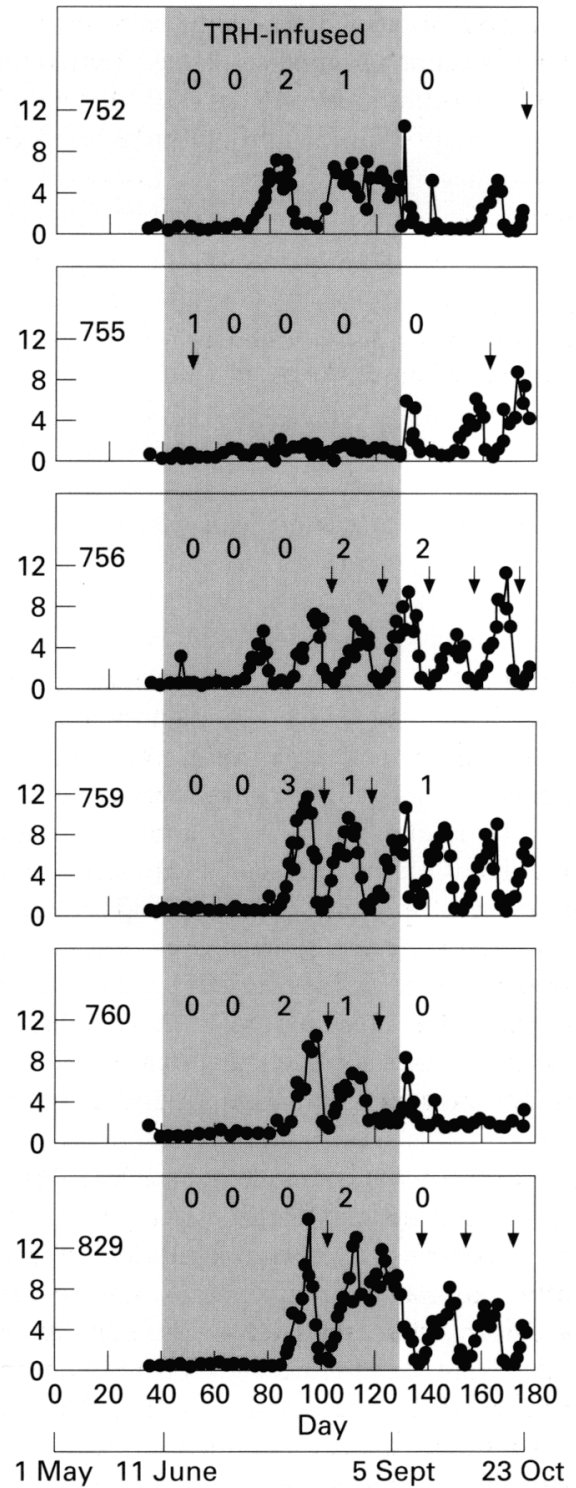

Fig. 2. Plasma concentrations of progesterone in control and thyrotrophin-releasing hormone (TRH)-infused ewes maintained under natural photoperiod at $57^{\circ} \mathrm{N}$ and receiving an oral dose of $3 \mathrm{mg}$ melatonin at $15: 00 \mathrm{~h}$ each day from 1 May. The shaded region indicates the period of TRH infusion. Individual ewe numbers are given on the left of each panel. The number of corpora lutea in relation to time of laparoscopy are given across the top of each panel. Arrows denote observed behavioural oestrus.

not, on its own, cause any of the disruptions in reproduction function that occurred.

In view of the preceding differences between experiments in the thyroxine status of the animals involved, the hypothesis that the increase in thyroxine in the present experiment was inadequate to delay the melatonin-induced activation of the $\mathrm{GnRH}$ pulse generator and behavioural oestrus in all ewes, yet was sufficient to induce a wide range of other abnormalities in reproductive function is attractive. Although we have no further observations to support this view, support for the general concept that it is only extremes of thyroid function that interfere with the photoperiod-induced pattern of reproduction can be found in studies involving various degrees of hypothyroidism. For example, chronic immunoneutralization of
TRH by active immunization reduced thyroxine concentrations to about $25 \mathrm{nmol} \mathrm{I}^{-1}$ but did not affect the duration of the ewe's breeding season (Fraser and McNeilly, 1982), whereas a more severe degree of hypothyroidism (thyroxine concentrations $\simeq 18 \mathrm{nmol} \mathrm{1}^{-1}$ ) induced by daily, oral dosing with methylthiouracil extended the breeding season (Follett and Potts, 1990). The authors of this latter study conclude that to completely prevent photorefractoriness and the transition to anoestrus, thyroxine concentrations would have to be reduced well below $10 \mathrm{nmol} \mathrm{I}^{-1}$.

At present the mechanisms involved in the induction, by TRH infusion, of the various abnormalities in reproductive function remain speculative. In the case of ewes exhibiting extended luteal phases during TRH infusion, the multifactorial 
nature of the mechanisms involved in normal luteolysis means that its inhibition could occur at a number of levels. These may involve inhibition of the synthesis and release of uterine prostaglandin $\left(\mathrm{PGF}_{2 u}\right)$ through a failure in the normal temporal expression of the uterine oxytocin receptor (Roberts et al., 1976), leading to reductions in inositol phosphate turnover and arachidonic acid production (Flint et al., 1986). The occurrence of suprabasal periovulatory progesterone concentrations, most noticeable in TRH-infused ewe 760 but also seen in ewes 752 and 759 , could be regarded as a less severe form of inhibited luteolysis. In cows, increased progesterone concentrations at ovulation are associated with reductions in both the incidence and intensity of behavioural oestrus and increases in the incidence of extended interovulatory intervals (Duckens et al., 1995). In the present experiment, a lower expression of behavioural oestrus and protracted interovulatory intervals are also two of the abnormalities associated with TRH infusion. In the only other study to investigate the effects of infused TRH on luteal function (McNeilly and Baird, 1983), luteolysis was induced using cloprostenol, a potent analogue of $\mathrm{PGF}_{2 a}$. Under these conditions, plasma progesterone concentrations during luteolysis declined at the same rate and to similar baseline values in control and TRH-infused ewes. In contrast, ovarian oestradiol production was suppressed by TRH infusion (McNeilly and Baird, 1983). This observation could explain the lower incidence of behavioural oestrus in TRH-infused compared with control ewes in the present study. It could also be a contributory factor to the higher incidence of extended luteal phases, in that oestradiol, via upregulation of the oxytocin receptor (Hixon and Flint, 1987), enhances the responsiveness of the uterus to oxytocin, thereby stimulating uterine $\mathrm{PGF}_{2 a}$ secretion and luteolysis (Silvia et al, 1991).

In conclusion, continuous TRH infusion of melatonin-treated ewes increased their plasma concentrations of prolactin, thyroxine and tri-iodothyronine but had no significant influence on ovulation rate or the timing of the breeding season. It was associated, however, with a wide range of abnormalities in ovarian function and endocrine status, the nature of which varied between ewes.

The authors are grateful to I. Robertson and M. Cheyne for technical assistance, and the NIADDK and L. E. Reichert for hormone preparations and antiserum. The Rowett Research Institute is financed by the Scottish Office Agriculture, Environment and Fisheries Department.

\section{References}

Backstrom CT, McNeilly AS, Leask RM and Baird DT (1982) Pulsatile secretion of $\mathrm{LH}, \mathrm{FSH}$, prolactin, oestradiol and progesterone during the menstrual cycle Clinical Endocrinology 17 29-42

Chandrasekhar Y, D'Occhio MJ, Holland MK and Setchell BP (1985) Activity of the hypothalamo-pituitary axis and testicular development in pre-pubertal ram lambs with induced hypothyroidism or hyperthyroidism Endocrinology 117 1645-1651
Djahanbakhch O, Swanston IA, Corrie JET and McNeilly AS (1981) Prediction of ovulation by progesterone Lancet ii 1164-1165

Duckens $M$, Maciel $M$, Gustafsson H, Forsberg $M$, Rodriguez-Martinez $H$ and Edquist L-E (1995) Influence of perioestrous suprabasal progesterone levels on cycle length, oestrous behaviour and ovulation in heifers Animal Reproduction Science 37 95-108

Flint APF, Leat WMF, Sheldrick EL and Stewart HJ (1986) Stimulation of phosphoinositide hydrolysis by oxytocin controls prostaglandin synthesis in the ovine endometrium Biochemical Journal 237 797-805

Follett BK and Potts C (1990) Hypothyroidism affects reproductive refractoriness and the seasonal oestrous period in Welsh Mountain ewes Journal of Endocrinology 172 103-109

Fraser HM and McNeilly AS (1982) Effect of chronic immunoneutralization of thyrotrophin-releasing hormone on the hypothalamic-pituitary-thyroid axis, prolactin, and reproductive function in the ewe Endocrinology 111 1964-1973

Hixon JE and Flint APF (1987) Effects of a luteolytic dose of oestradiol benzoate on uterine oxytocin receptor concentrations, phosphoinositide turnover and prostaglandin $\mathrm{F}_{2 u}$ secretion in sheep Journal of Reproduction and Fertility $\mathbf{7 9}$ 457-467

Karsch FJ, Bittman EL, Foster DL, Goodman RL, Legan SJ and Robinson JE (1984) Neuroendocrine basis of seasonal reproduction Recent Progress in Hormone Research 40 185-232

McNeilly AS and Baird DT (1983) Direct effect of prolactin, induced by TRH injection, on ovarian oestradiol secretion in the ewe Journal of Reproduction and Fertility $69559-568$

McNeilly AS and Andrews P (1974) Purification and characterization of caprine prolactin Journal of Endrocinology 60 359-367

McNeilly AS, Jonassen JA and Fraser HM (1986) Suppression of follicular development after chronic LHRH immunoneutralization in the ewe Journal of Reproduction and Fertility 76 481-490

Nicholls TJ, Follett BK, Goldsmith AR and Pearson H (1988) Possible homologies between photorefractoriness in sheep and birds; the effect of thyroidectomy on the length of the ewe's breeding season Reproduction Nutrition Development 28 375-385

O'Callaghan D, Wendling A, Karsch FJ and Roche JF (1993) Effect of exogenous thyroxine on timing of seasonal reproductive transitions in ewes Biology of Reproduction 49 311-315

Roberts JS, McCracken JA, Gavagan JE and Soloff MS (1976) Oxytocinstimulated release of prostaglandin $\mathrm{F}_{2 u}$ from ovine endometrium in vitro: correlation with estrous cycle and oxytocin receptor binding Endocrinology 99 1107-1114

Robinson JJ, Wigzell S, Aitken RP, Wallace JM, Ireland S and Robertson IS (1991) The modifying effects of melatonin, ram exposure and plane of nutrition on the onset of ovarian activity, ovulation rate and the endocrine status of ewes Animal Reproduction Science 26 73-91

Robinson JJ, Wallace JM, Aitken RP and Wigzell S (1992) Effect of duration of melatonin treatment on the onset and duration of oestrous cyclicity in ewes Journal of Reproduction and Fertility 95 709-717

Robinson JJ, Wallace JM, Aitken RP and McNeilly AS (1993) Effect of chronic treatment with a $\mathrm{GnRH}$ agonist to suppress pulsatile $\mathrm{LH}$ secretion on the ability of exogenous melatonin to advance oestrous cyclicity in ewes Journal of Reproduction and Fertility $99601-608$

Shi ZD and Barrell GK (1992) Requirement of thyroid function for the expression of seasonal reproductive and related changes in red deer (Cervus elaphus) stags Journal of Reproduction and Fertility 94 251-259

Silvia WJ, Lewis GS, McCracken JA, Thatcher WW and Wilson L, Jr (1991) Hormonal regulation of uterine secretion of prostaglandin $F_{2,2}$ during luteolysis in ruminants Biology of Reproduction 45 655-663

Webster JR, Moenter SM, Woodfill CJI and Karsch FJ (1991) Role of the thyroid gland in seasonal reproduction. Il. Thyroxine allows a seasonspecific suppression of gonadotropin secretion in sheep Endocrinology $\mathbf{1 2 9}$ 76-183 